\title{
Philosophy of Yamuna and Its Subcultural Roots
}

\author{
Ruzana Pskhu \\ Department of Social Philosophy \\ Peoples' Friendship University of Russia \\ Moscow, Russia \\ r.pskhu@mail.ru
}

\begin{abstract}
The main themes of tantric doctrines are connected with different means of the inner and outer worship of some deities, recitation of mantras, forms of yogic meditation, description of supernatural abilities (siddhi), structure of an individual psychophysical organization, cakra, and etc. Here we consider tantra in a wide sense (denoting all three sections of tantric literature), rather than in a narrow sense as a Sakti tantrism only. The paper deals with the philosophical argumentations of Yāmuna, the first philosopher of viSiX[Advaita who put against the Orthodox negation PAVcarAtrAgama tradition.
\end{abstract}

Keywords-Tantra; viSiX[Advaita; PAVcarAtrAgama; Oberhammer; RAmAnuja; Indian Philosophy; Yämuna; emancipation; bhakti

\section{INTRODUCTION}

The theological aspects of the philosophy of viSiX[Advaita have many references to the PAVcarAtra tradition which is usually defined as a tantric tradition with some restrictions. The term PAVcarAtra (sanskr. five nights) is applied to vaiXNava Agamic texts and has attributed to the Satapatha brAhmaNa 12.6 where NArAyaNa performed a sacrifice for five nights and became a transcendent and immanent being. The PAVcarAtrAgamas constitute the most important texts of SrIvaiXNava sampradAya of RAmAnuja. It is composed of more than 200 texts dated between the 3rd century and 600-850 AD but only among them. Two texts are canonical, the Sāttvata Tantra and Jayākhya SaMhita. RAmAnuja (1077-1157), established the PAVcarAtra system of VaiXNavism for his followers and based his philosophy of NArAyaNa worship on the PAVcarAtric texts.

\section{PHILOSOPHICAL SYSTEM OF YAMUNA AND ITS TANTRIC ELEMENTS}

As we know, the significance of PAVcarAtrAgama was revealed by Yāmuna (918-1038), who collaborated on the basic principles of viSiX[Advaita philosophy (Brahman as the Supreme Prson with unlimited auspicious attributes; bhakti as the most powerful spiritual path; the inseparable relationship of the individual soul and Brahman; and etc.). He established a philosophical argumentation for the valid involvement of all religious (PAVcarAtric) elements into the philosophy of viSiX[Advaita's system. In the scanty works

The paper is prepared in the frames of the project supported by the grant of the Russian Science Foundation (RSF) № 16-18-10427. of Yāmuna, one can find the doctrine of absolute dependence of the world and individual souls on Brahman in his highest form $\mathrm{ViXNu}$, the doctrine of bhakti as intellectual love for God, which includes the ways of karma and jVAna, the doctrine of reality which is not non-individual. Nonetheless, the philosophical ideas of Yāmuna have still to be studied in depth.

The base of the philosophy of Yāmuna are Prasthānatrayī's texts, but the key role in forming of that tradition belongs to the texts of $\mathrm{ViXNu}$ tradition (PAVcarAtra, texts of Alvars, ViXNu purANa, and etc.). The work in which Yāmuna provides the argumentation for PAVcarAtra tradition is titiled as "AgamaprAmANya" (or "The Validity of [PAVcarAtra tradition]"). The "AgamaprAmANya" has a key role in the process of becoming of viSiX[Advaita. It is written by the educated Brahmin, who is very wise in the Vedic knowledge, and open to the PAVcarAtra tradition, ready to protect it from those who assert its non-Vedic origin. After the advaita and bhedAbheda philosophical systems, based upon Upanishads texts, Yāmuna involved absolutely new texts in the vedAnta philosophical tradition. He does not only prove the theistic vedAnta, but also argues it is using with the help of the texts which were regarded as non-orthodox (non-uttara-mImāNsA) tradition. In other words, not only did he take some type of heretic viXNuistic texts as canonical one, but also did reasoning within the frame of Vedic tradition. It was an attempt to gain the harmonization of PAVcarAtra tantric tradition and vedAnta philosophical tradition, being aware that the former was rejected by the author(s) of "Brahma sutras". In the opinion of Yāmuna PAVcarAtrAgama, though not connected with the Vedic literature, it has the same authority and validity as Veda has. His main reason is that both traditions are not contradictory to each other but are relied on Brahman or $\mathrm{ViXNu}$. Later, the philosophical integration of tantric elements into the philosophy of viSiX[Advaita was continued by RAmAnuja.

Taking into account some works of Yāmuna, we can say that, in the 8th century, there were attempts to re-interpret the philosophical ideas of vedAnta. The philosophical ideas of Nāthamuni were developed in the works of Yāmuna, and it shows that their attempts of non-vedāntic tradition to penetrate into the vedAnta in the period of strong polemics between advaita and bhedābheda and the important factor of becoming viSiX[Advaita was the ViXNu tradition which was represented by South Indian saints or Alvars. Their 
creative ideas, poetry and images became a base of the philosophical system of vedAnta.

In fact, there were different doctrines of Vedic and nonVedic origin, one of them rejecting any possibility of comparison. Meanwhile, the latter one imitated the former. In this situation, Yāmuna made the first step to crush the arrogant spirit of vedAnta saying that both traditions tell about the same God whose name is ViXNu. This statement was confirmed with strong philosophical arguments based on good ideas about the God, soul and means of self-realization which are the main contents of "MahāpUruXanirNaya" and "AgamaprAmANya": both texts present proof that the Highest Reality is the Highest Purusha, NArAyaNa.

In "AgamaprAmANya", Yāmuna starts with defending validity of PAVcarAtrAgama, arguing against those whose "minds are confused by the noise of multitudes of sophisms and falsehoods", refusing "to accept the authority of PAVcarAtra tantra which, being composed by the Supreme Person Himself, leads to unparalleled beatitude" [1].

The argumentation of these people who deny the authority of PAVcarAtra tantra is the following:

- If it is a verbal testimony, then it should depend on other authority or be independent testimony. It doesn't depend on anything that it means that it must, by definition, be independent. Perception and other means of knowledge cannot produce the knowledge that the PAVcarAtra tantra sets forth that the release can be attained by means of some ritual acts (like consecration or worship of the Bhagavān). To that, Yāmuna says that there is someone in whom finite qualities subsist in an infinite condition and this person to be the Bhagavān who has perceptual knowledge that Consecration etc are dharma.

- Perceptual knowledge can never go beyond its own sphere. You cannot conclude from finite perception to infinite perception. That would mean that either the infinite exists in the finite or the finite gradually becomes infinite. Since the authority of PAVcarAtra tantra is based on the perception, its authority is entirely non-existent. Moreover, PAVcarAtra tantra means of release cannot be inferred from the Scripture. This tantra cannot be proved by perception, inference, verbal testimony or analogy. To that, Yāmuna replies that we can, in the same argument, put forward against the tradition of Manu: either both are authoritative or neither is. There are no grounds to say that the wo traditions differ in some essential respect.

- Bhāgavatas are not Brahmins: hair-tuft, sacred thread and etc., which are prescribed for Brahmins, do not make a man a Brahmin because their conduct proves that they cannot be Brahmins. They perform puja to the Deity for a living and eat the food which is offered to the idols. All of these things disqualify them as Brahmins. If PAVcarAtra tantra recognizes the authority of the Bhāgavatas, who by birth and by deeds have derivated from Veda, it is a sufficient ground to deny authority of PAVcarAtra tantra. Moreover, PAVcarAtra tantra is not among the fourteen sources of knowledge which all orthodox people recognize as giving authoritative information on the Law.

In this text, Yāmuna involves the philosophical ideas of nyAya and the PrAbhAkara systems just to discover the false foundation of their argumentation. For the nyAya thesis that God can be proved by inference, Yāmuna puts the idea that God need not to be proved by inference because he is proved only by scripture, which is informative enough and moreover has the absolute authority. Dasgupta, who deals with Yāmuna's philosophy, says that, in his argumentation of God's existence, Yāmuna follows the method of nyāya, trying to prove that the world is the effect and is result of creation of a person. Other scholars argue that Yāmuna couldn't follow the method of nyāya because, as we can see in his "AgamaprAmANya", he says that the Scripture is the only source of knowledge of the Creator of the world [2]. Now the following question is actual: does Yāmuna really prove the existence of the Personal God, based on nyāya, or is the Scripture the only source of our knowledge about God? To answer this question, it is interesting to deal with the status of LakXmI in philosophy of Yāmuna. According to PAVcarAtra, LakXmI is equal to ViXNu in all aspects, and this divine pair constitutes one reality. If we take RAmAnuja's system, we can see that he doesn't prove this equality but ignores LakXmI when he deals with serious philosophical problems.

If we take "CatuHSlok $\vec{\imath}$ " by Yamunācarya, we see that it can be regarded as the concentrated expression of Yāmuna's ideas about the nature and essence of LakXmI. He presents LakXmI as a spouse of $\mathrm{ViXNu}$ and as a mediatrix between believers and the God. Later ideas of the viSiX[Advaita school can be traced to that hymn and the relationship between SrI and Brahman can be equaled with those between prakRti and puruXa. LakXmI, in this sense, is a power of prakRti, and a believer should pray this nature before praying to God. Here we see the idea that all outside features of ViXNu also belong to LakXmI, who is his beloved (kānta).

It is very interesting to see the term yavanika (veil) - a detail of women's clothing. In a sense, we can say that this veil covers the face of LakXmI. Another interesting term is vedātma, meaning "the soul of Veda" and is an epithet of $\mathrm{ViXNu}$. In other words - vāhana means that not only Garu]a is an animal of $\mathrm{ViXNu}$ but $\mathrm{ViXNu}$ himself is a vāhana of LakXmI because she is in his heart. The main ideas are that LakXmI possesses mercy, and she is the only queen of the world (lokaikeSvarI) and Yāmuna expresses his readiness to fall to her feet in devotion; the idea of that salvation is possible only due to compassion of LakXmI (karuNA) and her mercy (prasāda). The idea is that there are two forms of Reality: the first one is an expression of pure spiritual qualities of Brahman (peacefulness - Santa, eternity - ananta, powerfullness - mahāvibhuti), and the second one is his embodied form (mUrta), which has an image. It is very interesting that Yāmuna estimates the second form as a higher one. According to Yāmuna, LakXmI and ViXNu are 
inseparable, and all visible forms of ViXNu's appearance correspond with the hidden qualities of LakXmI.

If we take the works of RAmAnuja, we can see that LakXmI plays an eminent role only in the text of "SaraNāgatigadyam". In his other works, there are only sporadic references to her - citation from Upanishads and etc. In "SaraNāgatigadyam", though RAmAnuja admits the high position of LakXmI, he also tries to put forward ViXNu underlying that she only corresponds to him, but the final salvation depends only on Brahman's will. Some scholars say that it is because of philosophical reason: there must be only one cause of the world, and, if we also pray to LakXmI, then it can be very shakable for the unique position of Brahman as the only cause of the world. Reality is single and it is $\mathrm{ViXNu}$, and anything else is only an addition to him, including LakXmI. From the philosophical point of view, there is no possibility to prove her existence. If we take the works of philosophers who lived after RAmAnuja, we see that, for example, VeNka[anAtha put LakXmI as the main mediatrix between God and a human soul. According to him, she has her own nature, and it differs from the nature of $\mathrm{ViXNu}$, though she is inseparably connected to him. She is not an unconscious form of $\mathrm{ViXNu}$, like his prakRti or personification of his mercy. She is a separate person - the spouse of $\mathrm{ViXNu}$ who is equal to him in everything and is under his power just because she wants it herself.

"SaraNāgatigadyam", or the dialogue of RAmAnuja with the divine spouses SrI-ViXNu, is the first part of prose trilogy "Gadyatrayi" (the other two are "SaraNāgatigadyam" and "VaikuN[hagadya"). In comparison to main philosophical treatises of RAmAnuja, "Gadyatrayi" is not associated with the bhakti doctrine or the way of loving knowledge, which is prepared by karma-mārga and jVAnamārga but with the prapatti doctrine or absolute selfsurrender on God which doesn't presuppose such a preparation. This fact made many scholars consider this work written later, not by RAmAnuja. We can see influence of Rāmāyana and Alvar poetry on it, but, nevertheless, it was RAmAnuja who involved basic idea of viSiX[Advaita philosophy.

The text starts with address to Shree, in which RAmAnuja describes her good qualities. Having taken her blessing, RAmAnuja begins to describe ViXNu's appearance. This picturesque description can be considered the essence of his theology. In other words, the image of $\mathrm{ViXNu}$ is a common denominator of all philosophical complicated questions or contradictions. Then, RAmAnuja describes the way of salvation which is connected with the term of prapatti in the later tradition. RAmAnuja uses the term bhakti, but behind it there is an idea of self-surrender which was philosophically proved in "VedārthasaMgraha" and "SrIbhAXya".

As Oberhammer mentions in his article "The Influence of Orthodox VaiXNasim on viSiX[Advaita and PAVcarAtra", there is a gap in the contemporary investigations of becoming RAmAnuja school, the intellectual circumstances and the role of PAVcarAtra in that process. Both RAmAnuja philosophy and PAVcarAtra tradition were in the given atmosphere of some theological and philosophical discussions [3].

The ViXNu tradition that belongs to Vedic religious and philosophical tradition has Brahmanic rituals and must be created with the Brahmanic style of thinking. At the time of RAmAnuja, this tradition had been already monotheistic and had been formed by the vedāntic theology. It is possible that this tradition was created by the religious movement of Alvars, which brings the core of pious spirituality into viSiX[Advaita, but the Alvars didn't contribute much in forming the ViXNu ideas of RAmAnuja school. There were some scholastic systems like bhedābheda-vāda of Bhāskara (VIII c.) or YādavaprakāSa (XI c.) but none of them, even Nathamuni, created the central theological ideas of viSiX[Advaita.

\section{CONCLUSION}

Nevertheless, the viSiX[Advaita of RAmAnuja cannot be traced only to the ViXNu scholastics. In this case, there is a question: where from did these religious and theological aspects of the school arise? The aspects that could be traced not to PAVcarAtra but to another movement.

If we take BrahmasUtra's tradition, we can see that there is not any necessity in theology of SrI, nor vibhuti or SaraNāgati. PAVcarAtra itself needs this theological model: we cannot deduce from PAVcarAtric rituals any theology. Theology comes before practice. Theology of viSiX[Advaita can be characterized with the notion of relative being of Brahman, which is created by the ontological difference between the highest Brahman (paramātman), spiritual (cit) and non-spiritual (acit) objects of this world.

This ontological difference and the notion of relative being of Brahman gave viSiX[Advaita possibility to adopt the religious ideas of PAVcarAtra: RAmAnuja tries to interpret PAVcarAtra by means of his own doctrine and idea of God. He interprets that Vasudeva is identical with Brahman and manifests himself through 4 vyUha and other divine essences but, at the same time, saying that Brahman is transcendent. In other words, we cannot regard PAVcarAtra as scholastic environment in which the specific RAmAnuja doctrine of Brahman appeared.

Here a question arises: was the ViXNu tradition a basis for the school of RAmAnuja? Oberhammer analyses two passages from "ParamasaMhitā", which are connected with bhakti and appeal to ViXNu and says that all spirituality of SaraNāgati cannot be traced to PAVcarAtra but to the Vedic orthodox tradition. His main conclusion is: there must be a scholastic viXNuistic orthodoxy, which would be connected with philosophical and theological thought. That tradition was fixed in viSiX[Advaita and influenced PAVcarAtra and its religiosity and thought it was restricted by PAVcarAtra and South Indian traditions. The representatives of this tradition were Bhāskara and YādavaprakāSa, who probably had their own theology of the Goddess (rejected by VeNka[anAtha in his commentary on "CatuHSlok $\vec{\imath}$ " of Yāmuna) [4]. 
Despite of the fact of disregarding PAVcarAtra's role in viSiX[Advaita philosophy by many of its researchers, we can see that basic philosophical and theological models of this system cannot be adequately understood without taking into consideration of the tantric elements contained in PAVcarAtra texts and are latently present in the philosophical argumentation for viSiX[Advaita principles.

\section{REFERENCES}

[1] Yāmuna's Agama Pramanyam, or Treatise on the Validity of PAVcarAtra Sanskrit text with Engl. transl. by J. Van Buitenen. Madras.

[2] Dasgupta, Surendranath. 1975. History of Indian Philosophy. Delhi, vol. 3 .

[3] Oberhammer, Gerhard. 2007. The Influence of Orthodox VaiXNavism on viSiX[Advaita and PAVcarAtra. In Studies in Hinduism IV. On the Mutual Influence and Relationship of viSiX]Advaita vedAnta and PAVcarAtra. Ed. by G. Oberhammer and M. Rastelli. Wien, pp. 37-54.

[4] Czerniak-Drozdzowicz, Marzenna. 2003. PAVcarAtra Scripture in the Process of Chance. A Study of the ParamasaMhitA. Vienna: Publications of the De Nobili Research Library, vol. XXXI. 